\title{
Linking glacially modified waters to catchment-scale subglacial discharge using autonomous underwater vehicle observations
}

\author{
Laura A. Stevens ${ }^{1}$, Fiamma Straneo ${ }^{2}$, Sarah B. Das ${ }^{3}$, Albert J. Plueddemann ${ }^{2}$, Amy L. Kukulya ${ }^{4}$, and \\ Mathieu Morlighem ${ }^{5}$ \\ ${ }^{1}$ Massachusetts Institute of Technology/Woods Hole Oceanographic Institution Joint Program in Oceanography/Applied \\ Ocean Science and Engineering, Woods Hole, MA 02543, USA \\ ${ }^{2}$ Department of Physical Oceanography, Woods Hole Oceanographic Institution, Woods Hole, MA 02543, USA \\ ${ }^{3}$ Department of Geology and Geophysics, Woods Hole Oceanographic Institution, Woods Hole, MA 02543, USA \\ ${ }^{4}$ Department of Applied Ocean Physics and Engineering, Woods Hole Oceanographic Institution, \\ Woods Hole, MA 02543, USA \\ ${ }^{5}$ Department of Earth System Science, University of California, Irvine, Croul Hall, Irvine, CA 92697, USA
}

Correspondence to: Laura A. Stevens (stevensl@mit.edu)

Received: 29 July 2015 - Published in The Cryosphere Discuss.: 1 September 2015

Revised: 27 January 2016 - Accepted: 3 February 2016 - Published: 24 February 2016

\begin{abstract}
Measurements of near-ice ( $<200$ m) hydrography and near-terminus subglacial hydrology are lacking, due in large part to the difficulty in working at the margin of calving glaciers. Here we pair detailed hydrographic and bathymetric measurements collected with an autonomous underwater vehicle as close as $150 \mathrm{~m}$ from the ice-ocean interface of the Saqqarliup sermia-Sarqardleq Fjord system, West Greenland, with modeled and observed subglacial discharge locations and magnitudes. We find evidence of two main types of subsurface glacially modified water (GMW) with distinct properties and locations. The two GMW locations also align with modeled runoff discharged at separate locations along the grounded margin corresponding with two prominent subcatchments beneath Saqqarliup sermia. Thus, near-ice observations and subglacial discharge routing indicate that runoff from this glacier occurs primarily at two discrete locations and gives rise to two distinct glacially modified waters. Furthermore, we show that the location with the largest subglacial discharge is associated with the lighter, fresher glacially modified water mass. This is qualitatively consistent with results from an idealized plume model.
\end{abstract}

\section{Introduction}

Greenland Ice Sheet mass loss quadrupled over the last 2 decades, contributing roughly $7.4 \mathrm{~mm}$ to global sea level rise from 1992 to 2011 (Shepherd et al., 2012), and increasing freshwater inputs into the North Atlantic (Bamber et al., 2012). Ice sheet mass loss occurs through runoff of surface melt, ice discharge through iceberg calving, and submarine melt at marine-terminating outlet glacier margins (Van den Broeke et al., 2009; Enderlin et al., 2014). The synchronous retreat and speedup of marine-terminating glaciers in southeast Greenland in the early 2000s was likely initiated by a dynamic change at marine termini (Van den Broeke et al., 2009; Rignot and Kanagaratnam, 2006; Thomas et al., 2009), and points towards common external forcings from the warming atmosphere (Box et al., 2009) and/or ocean around Greenland (Straneo and Heimbach, 2013), though the exact forcing mechanisms and relative magnitudes remain unclear (Joughin et al., 2012; Straneo et al., 2013).

Increased submarine melt rates at outlet glacier marine termini may be a leading cause of Greenland Ice Sheet outlet glacier speed up and retreat (Holland et al., 2008; Joughin et al., 2012; Motyka et al., 2013; Post et al., 2011). The heat to drive submarine melting is supplied by waters from the subpolar North Atlantic and Arctic seas, whose circulation inside the fjords is a result of processes across a range of 
spatiotemporal scales (Jackson et al., 2014; Straneo et al., 2010). Ultimately, melt rates are affected by ocean properties (temperature and stratification) and circulation in nearice waters $(<200 \mathrm{~m})$ (Jenkins et al., 2010). Submarine melting is thought to be enhanced in summer as a result of meltwater runoff along the ice sheet bed entering the fjord across the grounding line as subglacial discharge, which provides an additional buoyancy source alongside submarine melt for initiating buoyant plumes along the terminus face (Jenkins, 1999, 2011; Sciascia et al., 2013; Xu et al., 2013). Relatively fresh waters rising in the core of these plumes become denser as they entrain salty ambient fjord waters, and this entrainment driven by plumes serves as a mechanism for transporting ambient fjord waters to the glacier face (Jenkins, 1999, 2011; Sciascia et al., 2013; Xu et al., 2013).

Plume theory and models combined with melt rate parameterizations suggest that higher subglacial discharge rates are associated with faster flows and entrainment of a greater volume of ambient fjord waters leading to higher submarine melt rates (Jenkins, 1999, 2011; Sciascia et al., 2013; $\mathrm{Xu}$ et al., 2013; Carroll et al., 2015); however, ocean property and plume measurements needed to inform and validate model simulations and theory are lacking due to difficulty in working at the margin of calving glaciers (Straneo and Cenedese, 2015). As a result, current modeling-sourced estimates of submarine melt rates at tidewater glaciers and their sensitivity to external forcings of the near-ice environment are highly uncertain, and based on unconstrained models of plume dynamics using ice-ocean boundary parameterizations forced by far field $(>1 \mathrm{~km})$ ocean property measurements and largely unknown subglacial discharge magnitude and distribution (Jenkins, 2011; Kimura et al., 2014; Sciascia et al., 2013; Slater et al., 2015; Xu et al., 2012, 2013). For example, in a recent numerical study the spatial distribution of subglacial discharge along the grounding line was found to have a large effect on both the total submarine melt rate and its distribution along marine termini (Slater et al., 2015). With a lack of observations of both the near-ice environment and subglacial discharge configurations, we are unable to define likely subglacial discharge scenarios and their associated influence on ice-ocean interactions, resulting in an inadequate and untested understanding of how tidewater glaciers respond to oceanic forcing now and in the future (Straneo and Cenedese, 2015). Specifically, ocean measurements collected at distances $>1 \mathrm{~km}$ from the glacier terminus provide limited information on the near-ice processes because the signals of glacial modification have, by that time, largely been smeared by lateral mixing processes. Indeed, the picture that emerges from such far-field measurements is of a horizontally invariant overturning cell (Chauché et al., 2014; Inall et al., 2014; Johnson et al., 2011; Mortensen et al., 2011; Straneo et al., 2011; Sutherland et al., 2014).

In this study, we present fjord hydrography and bathymetry measurements from the near-ice environment of a tidewater glacier in west Greenland (Fig. 1) that allow us

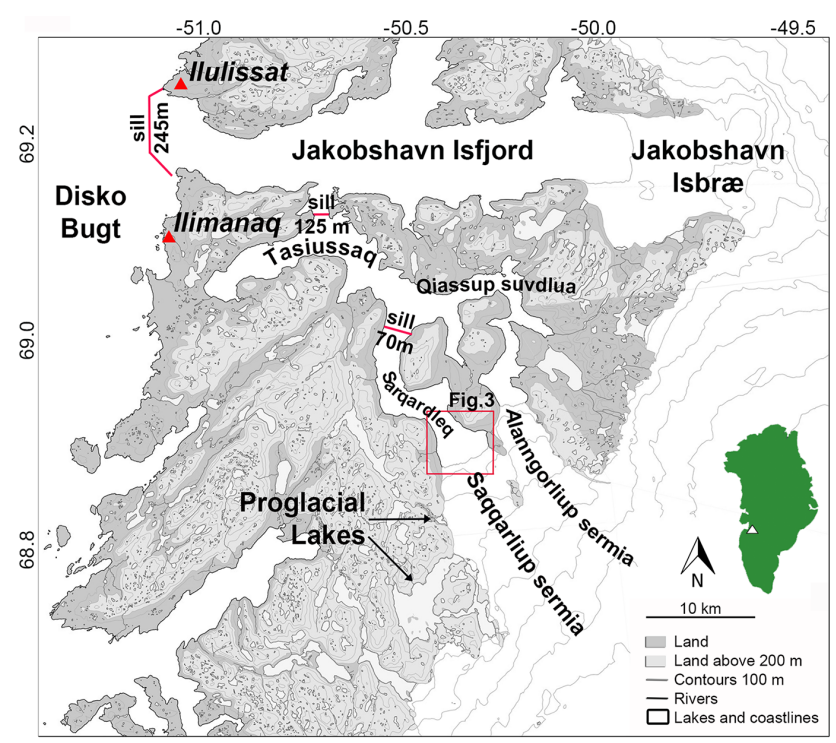

Figure 1. The Sarqardleq Fjord-Saqqarliup sermia outlet glacier system in West Greenland. Modified from NunaGIS 1: 100000 map (Asiaq, Greenland Survey). Sill locations shown in red. Figure 3 location shown in red box.

to reconstruct the distribution of subglacial discharge and provide key details on the ice-ocean exchanges. We do this by identifying the distribution of glacially modified water (GMW) - a product of ambient fjord waters mixing with subglacial discharge and glacial melt, including cooling due the melting of ice (Jenkins, 2011; Straneo et al., 2011) within a few $100 \mathrm{~m}$ of the glacier face, and by delineating the subglacial catchments that route subglacial meltwater to discharge locations along the grounded terminus. These hydrographic measurements were obtained primarily in July 2012, using a REMUS-100 (remote environmental measuring units) autonomous underwater vehicle (AUV) (Fig. 2a) to observe the temperature, salinity, and turbidity of waters in Sarqardleq Fjord (SF) from $\sim 2 \mathrm{~km}$ away to within a couple hundred meters of Saqqarliup sermia (SS) (Sarqardliup sermia in Old Greenlandic), a medium-sized tidewater glacier in West Greenland $\left(68.90^{\circ} \mathrm{N}, 50.32^{\circ} \mathrm{W}\right)$ (Fig. 1). This novel, high-risk field campaign was successful in obtaining multiple vertical sections of fjord water properties as close as $150 \pm 25 \mathrm{~m}$ from the terminus as well as detailed bathymetry of the previously unmapped fjord.

\section{Field campaign}

\subsection{REMUS-100 AUV}

The REMUS-100 AUV is a small (1.8 m-long) and light $(45 \mathrm{~kg})$ vehicle, rated to $100 \mathrm{~m}$-depth that has been modified for under-ice exploration (Plueddemann et al., 2012) (Fig. 2a). REMUS environmental sensors in- 

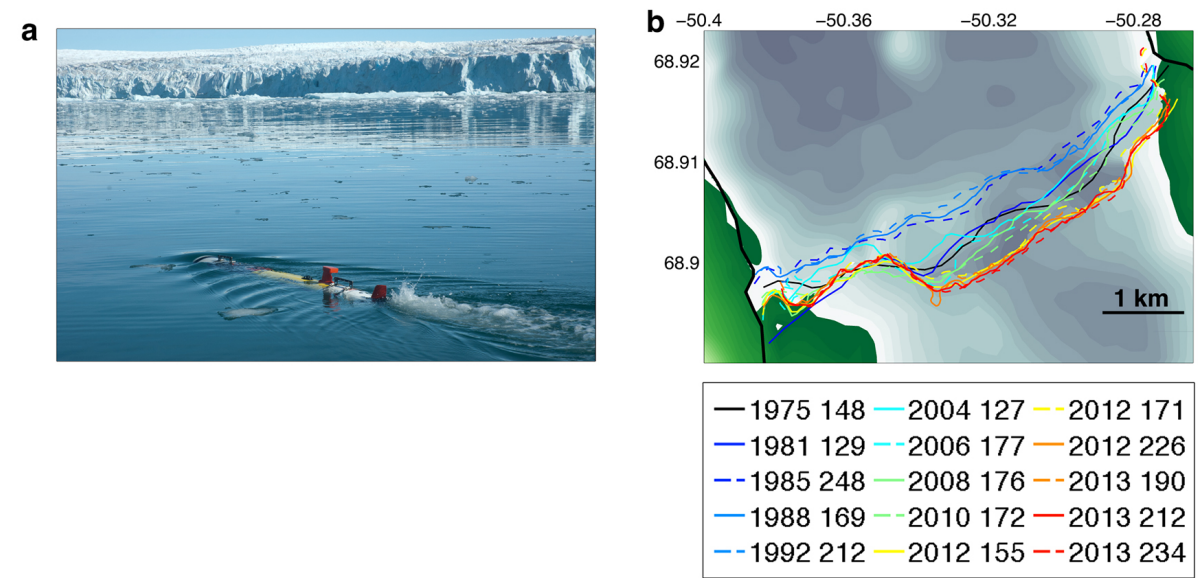

Figure 2. REMUS-100 AUV and past Saqqarliup sermia terminus positions in Sarqardleq Fjord. (a) REMUS-100 AUV before deployment in Sarqardleq Fjord. Note dense ice cover along Saqqarliup sermia terminus. (b) Saqqarliup sermia terminus 1975-2013 summertime positions digitized from the Landsat archive (http://earthexplorer.usgs.gov/) over fjord bathymetry and subglacial topography (see Fig. 3). Front position dates are listed in the legend as year and day of year.

cluded a Neil Brown Ocean Systems conductivity-depthtemperature (CTD) sensor, a WetLabs Environmental Characterization Optics (ECO) Triplet sensor, and a TeledyneRDI dual (upward and downward looking) $1200 \mathrm{kHz}$ acoustic Doppler current profiler (ADCP). The ECO Triplet provides measurements of turbidity from backscatter at $660 \mathrm{~nm}$. At the surface, REMUS communications include Iridium satellite telemetry, FreeWave $900 \mathrm{MHz}$ radio acoustic data telemetry, WiFi for local area network for wireless testing and configuration, and a Global Positioning System (GPS) receiver for location fixes at the start and end of missions. At depth, REMUS navigates by acoustically ranging to a network of three moored low-frequency (LF $10 \mathrm{kHz}$ ) longbaseline (LBL) transponders (Fig. 3). The vehicle continuously updates its position while underway through a combination of dead reckoning algorithms (which incorporate compass data, as well as propeller turns, water velocity and bottom track data from the ADCP), LBL fixes, and surface GPS fixes when available (see Plueddemann et al., 2012).

Field operations from the shore and in small boats took place from 17-27 July 2012 (DOY 199-209). SF is largely free of icebergs after spring sea-ice break up, though frequent calving along the SS terminus prevents boat travel within $\sim 200 \mathrm{~m}$ of the terminus. REMUS experienced navigational challenges in the fjord environment due to a confluence of factors including a strong surface pycnocline, loud and variable noise from calving and overturning of icebergs, and heavy ice conditions preventing some GPS fixes. Transects presented here include occasional deviations on the order of 5 to $50 \mathrm{~m}$ perpendicular to mission tracks. Data collected during mission track deviations are accepted and collapsed back onto the transect line.

Deployed over the side of a small fishing boat, and eventually from the shore, 11 REMUS missions were com- pleted over 9 days for both engineering and science objectives. Although a minor issue for the localization of water properties, the navigation challenges and track-line deviations caused significant uncertainties in the conversion from vehicle-relative to earth-referenced velocities. As a result, only measurements from the CTD and ECO Triplet are presented here. Combinations of yo-yo, fixed-depth, and fixedaltitude above-bottom sampling paths along transects parallel to the glacier face were used to acquire vertical sections of SF water properties. In total, 5 transects of temperature, salinity, and turbidity along 5 terminus-parallel sections (R1R5, Fig. 3) at distances 150 to $1500 \pm 25 \mathrm{~m}$ from the terminus selected based on REMUS navigation quality and best across- and along-fjord coverage are presented in this paper (Table 1).

\subsection{Hydrographic and turbidity data}

Profiles and sections presented here are made from alongtrack edited and smoothed REMUS CTD and ECO data. REMUS temperature and salinity data were edited with the removal of occasional erroneous points identified by an alongtrack first difference filter of density calculated from the temperature and salinity measurements. First differences of $>0.1$ sigma were removed, affecting $0.2 \%$ of the data. Turbidity values were capped at 10 nephelometric turbidity units (NTUs). Raw temperature and salinity data were obtained at $0.22 \mathrm{~s}$ intervals, while turbidity measurements were taken at $1.15 \mathrm{~s}$ intervals. Temperature, salinity, and turbidity measurements were interpolated to $0.5 \mathrm{~s}$ and then averaged over $2 \mathrm{~s}$ to obtain smoothed, along-track data for all sensors on a common time base with along-track resolution of 3.2$3.6 \mathrm{~m}$ (based on typical vehicle speeds that ranged between 1.6 and $1.8 \mathrm{~m} \mathrm{~s}^{-1}$ ). Contour maps of observed variables vs. depth and distance were created from the REMUS mission 


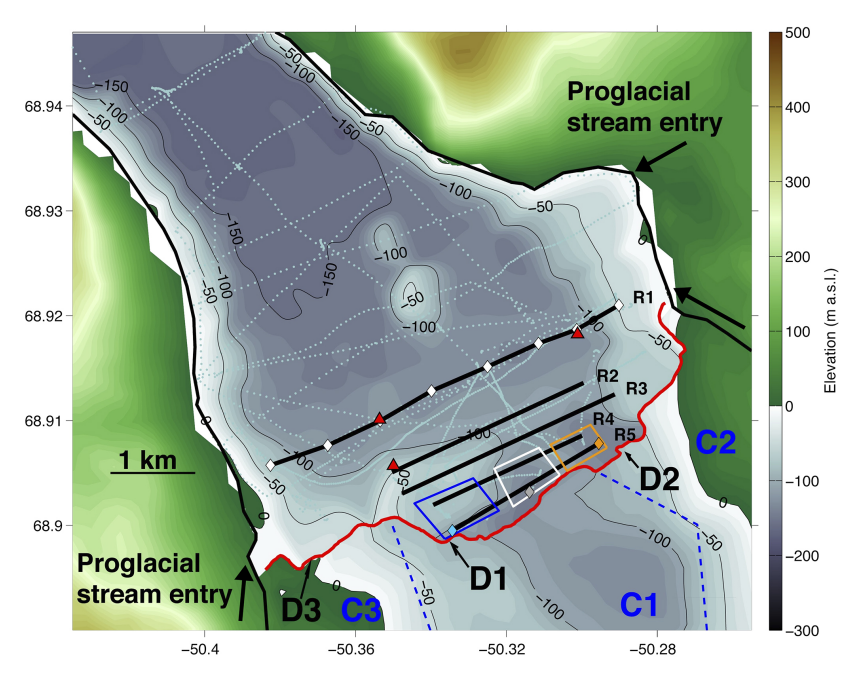

Figure 3. July 2012 Survey of Sarqardleq Fjord. Sarqardleq Fjord bathymetry ( $10 \mathrm{~m}$ colored contours below sea level within fjord) and Morlighem et al. (2014) bedrock elevation map (10 m colored contours above and below sea level outside of fjord) are shown. The Saqqarliup sermia front position and coastline from a 19 June 2012 Landsat image are mapped in red and black lines, respectively. Depth measurements collected during July 2012 field operations used to create the Sarqardleq Fjord bathymetry are plotted as grey dots over the contoured bathymetry. REMUS transects R1-R5 are shown in black, with LBL transponders mapped with red triangles. Subglacial subcatchments C1, C2, and C3 dividing lines from MBM2014 analysis are mapped in dashed blue line, with the location of D1, D2, and D3 subglacial discharge channels along the submerged terminus shown with thin black arrows. CTD casts are shown with diamonds: white diamonds are CTD casts along R1 used in REMUS cross-calibration, and the blue, gold, and grey diamonds are CTD casts 1, 2, and 3 that were taken along R5 within GMW1, GMW2, and the region between GMW1 and GMW2 (outlined in blue, gold, and white, respectively). Three proglacial stream entries to Sarqardleq Fjord are shown along the northeast and southwest fjord coastlines with thick black arrows.

tracks by optimal interpolation (kriging) of measurements collapsed along glacier face-parallel transect lines (Fig. 4). Simple, linear fits to computed autocorrelation were used for temperature, salinity, and turbidity. Kriging was completed over a depth and along-track distance range slightly larger than the data range, with a vertical resolution of $2 \mathrm{~m}$ and a horizontal resolution of $100 \mathrm{~m}$, based on the along-track resolution of $3 \mathrm{~m}$ and the horizontal distance between REMUS mid-depth sample lines of $100 \mathrm{~m}$, respectively. Sensitivity tests of different kriging models and linear slopes yielded little impact on resulting sections, demonstrating a robust kriging methodology.

Several shipboard CTD casts, collected using an RBR XR 620 CTD during the field campaign, are presented to supplement the REMUS observations (Fig. 6). Eight shipboard CTD casts were taken along the R1 transect (Fig. 3), 8 casts were taken along cross-fjord sections in the outer SF
( $>10 \mathrm{~km}$ from the SS terminus) (triangles in Fig. 7a), and 3 casts were taken roughly at the R5 midpoint, northeastern end, and southwestern end (Fig. 3). REMUS and CTD measurements were cross-calibrated by comparing REMUS R1 measurements with the 8 CTD casts taken along the R1 transect immediately following the completion of the REMUS R1 mission. $\theta, S$, and depth offsets were found to be $0.0015^{\circ} \mathrm{C},-0.05 \mathrm{PSU}$, and $-2.5 \mathrm{~m}$ respectively, between the CTD and REMUS measurements. The RBR XR 620 CTD was calibrated before and after the fieldwork, but the REMUS CTD was not. REMUS measurements were therefore adjusted by $2.5 \mathrm{~m}$ to match the CTD observations, and this offset is assumed to have remained constant throughout the campaign.

\subsection{Bathymetric data}

Detailed bathymetry of the previously unmapped SF was obtained through depth measurements from a shipboard singlebeam depth sounder, a shipboard ADCP, and the REMUS downward looking ADCP in bottom-track mode (Fig. 3). After removing occasional spikes in the REMUS ADCP depth soundings (outliers on the order of $15 \mathrm{~m}$ deeper than background), depth measurements across the sampling platforms at crossover points were consistent within $<4 \mathrm{~m}$. Coastline positions were assigned a depth of $0 \mathrm{~m}$, and were obtained from digitizing a 19 June 2012 Landsat image (30 m horizontal resolution). Depth measurements were combined across platforms by calculating a binned average depth measurement over a $25 \mathrm{~m} \times 25 \mathrm{~m}$ grid across the fjord. The Barnes Objective Analysis (Barnes, 1994) was used to interpolate the binned depth measurements with a $175 \mathrm{~m} \times 175 \mathrm{~m}$ search radius to create the bathymetry shown in Fig. 3. The bathymetry product aligns well with the binned depth measurements (less than $1 \mathrm{~m}$ offsets) except in the location of the northern side of the seamount $\left(68.92^{\circ} \mathrm{N}, 50.34^{\circ} \mathrm{W}\right)$, which contains the maximum offset from the gridded depth measurements at $\pm 5 \mathrm{~m}$. Due to low data coverage, the Barnes Objective Analysis was not extended to the outer regions of SF. However, with depth measurements from the shipboard echosounder we have mapped the fjord centerline depth to the confluence of SF and Tasiussaq Fjord, $15 \mathrm{~km}$ from the SS terminus (Figs. 1 and 7a).

\section{Physical setting: the Sarqardleq Fjord-Saqqarliup sermia outlet glacier system}

\subsection{Fjord bathymetry, subglacial topography, and historical terminus positions}

The Saqqarliup sermia-Sarqardleq Fjord (SS-SF) outlet glacier-fjord system is located in West Greenland roughly $30 \mathrm{~km}$ south of Jakobshavn Isbræ (Fig. 1). SS is a marine terminating outlet glacier with a $6 \mathrm{~km}$-wide terminus and an upstream subglacial catchment area of $400 \pm 50 \mathrm{~km}^{2}$ (Fig. 7a, 
Table 1. REMUS Missions in Sarqardleq Fjord.

\begin{tabular}{|c|c|c|c|c|c|}
\hline Mission & Date & $\begin{array}{l}\text { Local time } \\
\text { at mission } \\
\text { start }\end{array}$ & $\begin{array}{l}\text { Duration } \\
\text { (h:mm) }\end{array}$ & $\begin{array}{l}\text { Transect sampling path } \\
\text { (m depth) }\end{array}$ & $\begin{array}{r}\text { Distance } \\
\text { traveled } \\
(\mathrm{km})\end{array}$ \\
\hline R1 & 18 July & $21: 10$ & $1: 28$ & Yo-Yo $=5-90$ & 9.00 \\
\hline $\mathrm{R} 2$ & 21 July & $15: 37$ & $3: 41$ & $\begin{array}{l}\text { Yo-Yo }=5-50 \\
\text { Fixed depth }=50,70 ; \\
\text { Altitude }=10 \mathrm{~m} \text { above bottom }\end{array}$ & 23.11 \\
\hline R3 & 22 July & $14: 58$ & $6: 25$ & $\begin{array}{l}\text { Yo-Yo }=5-55 \\
\text { Fixed depth }=60,70 ; \\
\text { Altitude }=10 \mathrm{~m} \text { above bottom }\end{array}$ & 41.36 \\
\hline $\mathrm{R} 4$ & 23 July & $14: 37$ & $5: 05$ & $\begin{array}{l}\text { Yo-Yo }=5-50 \\
\text { Fixed depth }=60,70 ; \\
\text { Altitude }=10 \mathrm{~m} \text { above bottom }\end{array}$ & 30.93 \\
\hline R5 & 24 July & $18: 12$ & $5: 26$ & $\begin{array}{l}\text { Yo-Yo }=5-60 ; \\
\text { Fixed depth }=40,55,70 ; \\
\text { Altitude }=10 \mathrm{~m} \text { above bottom }\end{array}$ & 34.91 \\
\hline
\end{tabular}

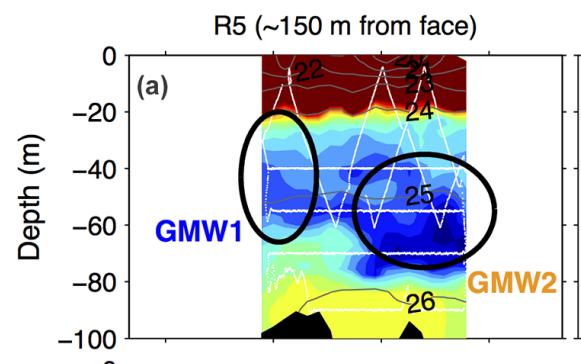

$\mathrm{R} 3(\sim 750 \mathrm{~m}$ from face $)$

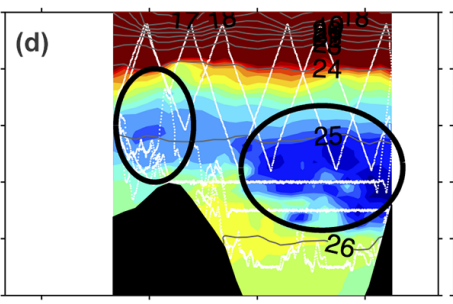

(e)
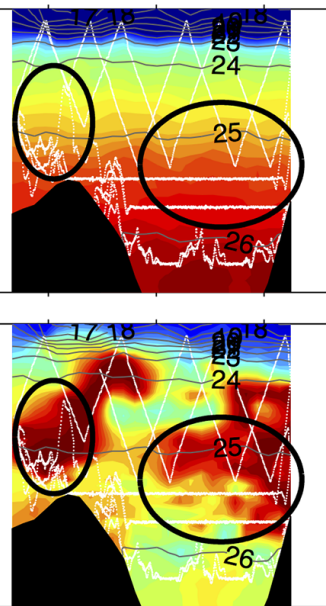

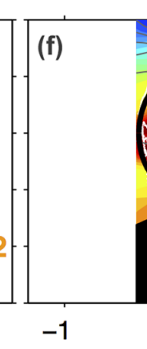

Distance along REMUS line from D1 (km)
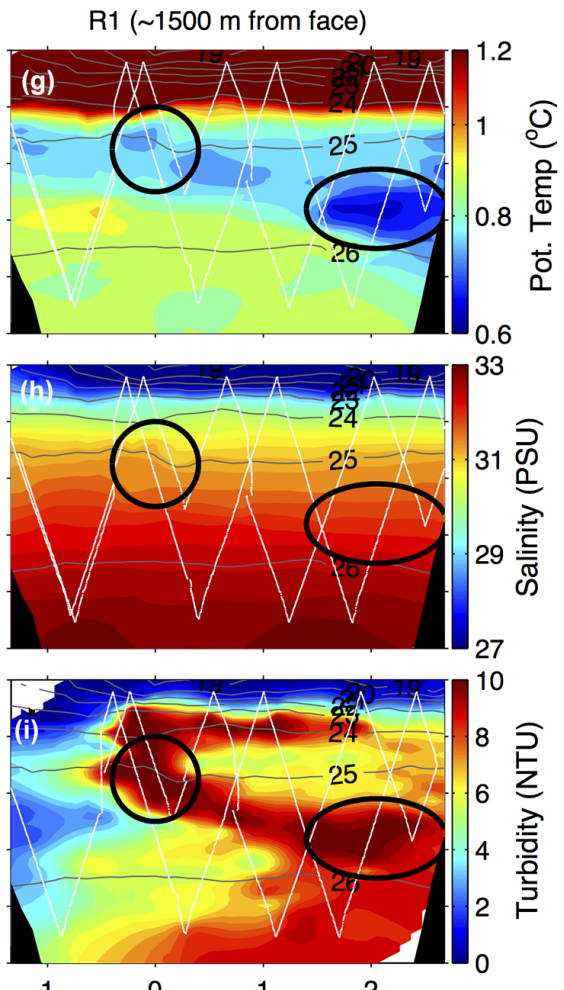

Figure 4. Select REMUS across-fjord sections. $\theta\left({ }^{\circ} \mathrm{C}\right), S$ (PSU), and turbidity (NTU) sections along REMUS lines (a)-(c) R5, (d)-(f) R3, and (g)-(i) R1 from 0 to $100 \mathrm{~m}$ depth. Sections are oriented looking away from the terminus, with the southwestern end of the section on the left. Across-fjord transect distance is plotted as horizontal distance along section, with $0 \mathrm{~km}$ located at the intersection of the REMUS section with an along-fjord line running from D1 to the southwestern LBL transponder along R1 (Fig. 3). GMW1 and GMW2 regions identified by black ellipses, and labeled in blue and gold, respectively in (a)-(c). Isopycnals plotted in grey, REMUS mission tracks shown in white (Table 1), and bathymetry shown in black (Fig. 3). 
Table 3; methods described in Sect. 3.2). We estimate total annual runoff out of this catchment to be on the order of $1 \mathrm{~km}^{3} \mathrm{yr}^{-1}$ using Regional Atmospheric Climate Model version 2.3 (RACMO2.3) runoff values (Van den Broeke et al., 2009) (methods described in Sect. 3.2). A bedrock trough 100-150 m b.s.l. (below sea level) extends $15 \mathrm{~km}$ inland from the terminus, and continues further inland as a bedrock trough above sea level (Morlighem et al., 2014) (Fig. 7a). The SS centerline ice thickness is $\sim 200 \mathrm{~m}$ at the terminus and increases inland (Morlighem et al., 2014) (Fig. 7a). The Saqqarliup sermia terminus position has been relatively stable in comparison to the large terminus retreats observed at other Greenland tidewater glaciers (Moon and Joughin, 2008) based on our analyses of LANDSAT imagery from 1979 to present (Fig. 2b). Modest advance and retreat phases on the order of $\pm 500 \mathrm{~m}$ are observed over recent decades, with a net retreat of $\sim 1 \mathrm{~km}$ within the center third of the glacier terminus observed from 1992 to present (Fig. 2b). Average flow velocities within the SS outlet glacier during the 2007-2009 winters were on the order of 125-175 $\mathrm{m} \mathrm{yr}^{-1}$, with the center third of the SS terminus reaching speeds of $200 \mathrm{~m} \mathrm{yr}^{-1}$ (Joughin et al., 2013).

The Sarqardleq-Tasiussaq Fjord system is the southern side fjord off the larger, deeper Jakobshavn Isbræ (JI) Fjord, which connects the largest and fastest Greenland ice stream (JI) to Disko Bugt (Fig. 1). From the SS terminus, the shallower Sarqardleq-Tasiussaq Fjord system extends roughly $30 \mathrm{~km}$ to the northwest before reaching JI Fjord. SF meets Tasiussaq Fjord over a previously unknown 70 m-deep sill, $15 \mathrm{~km}$ from the SS terminus (Figs. 1 and 7a). Tasiussaq Fjord meets JI fjord over an at most 125 m-deep sill (Gladish et al., 2015a) $30 \mathrm{~km}$ from the SS terminus (Fig. 1). Waters along the SS terminus range from 20-150 m-depth, and are deepest in two troughs near the center of the glacier (Fig. 3, Table 3$)$. Both SS lateral terminus regions are grounded in relatively shallow lagoons $(<20 \mathrm{~m})$ (Fig. 3). A $40 \mathrm{~m}$-deep seamount is located $2.5 \mathrm{~km}$ from the vertical SS calving face (Fig. 3).

\subsection{Subglacial catchment and runoff}

To first order, subglacial catchments are defined by ice sheet surface and bed topography, which governs subglacial hydraulic potential at the bed (Cuffey and Patterson, 2010). Gradients in subglacial hydraulic potential at the ice-sheet bed do not completely dictate subglacial meltwater pathways due to the constantly evolving subglacial hydraulic system over the summer melt season (Andrews et al., 2014; Chandler et al., 2013; Hewitt et al., 2012; Schoof, 2010), but subglacial hydraulic potential gradients are likely the dominant regional factor. This is supported by recent modeling studies, which find a strong topographic control of channelized subglacial meltwater routing over Greenland Ice Sheet outlet glaciers (Banwell et al., 2013; Palmer et al., 2011).
The SS catchment area was determined based on streamline analysis through subglacial hydraulic potential gradient fields to estimate which path water parcels located at the bed under inland ice will follow out to the coast. The downslope subglacial hydraulic potential gradient, $-\nabla \Phi_{\mathrm{h}}$, was calculated as follows:

$-\nabla \Phi_{\mathrm{h}}=-\rho_{\mathrm{i}} g\left[f_{\mathrm{W}} \nabla S+\left[\rho_{\mathrm{w}} / \rho_{\mathrm{i}}-f_{\mathrm{W}}\right] \nabla B\right]$,

where $\rho_{\mathrm{i}}$ is the density of ice, $\rho_{\mathrm{w}}$ is the density of freshwater, $g$ is the gravitational acceleration, $f_{\mathrm{w}}$ is the flotation fraction, and $\nabla S$ and $\nabla B$ are the surface and bed gradients, respectively (Cuffey and Patterson, 2010; Shreve, 1972). We assume water at the bed flows along the steepest subglacial hydraulic potential gradient (Shreve, 1972). We used two widely available bedrock elevation maps, Bamber et al. (2013) and Morlighem et al. (2014) (hereafter BBM2013 and MBM2014) to calculate $-\nabla \Phi_{\mathrm{h}}$ across a $1 \mathrm{~km}$ by $1 \mathrm{~km}$ grid (Bamber et al., 2013) and $150 \mathrm{~m}$ by $150 \mathrm{~m}$ grid (Morlighem et al. 2014) equivalent to the resolution of each bedrock elevation map. MBM2014 beneath SS was updated from the previously published map by adding our SF bathymetry measurements as a boundary constraint along the SS terminus in this otherwise data-sparse region. The MBM2014 used in this study is available online as IceBridge BedMachine Greenland, Version 2 from the National Snow and Ice Data Center (http://nsidc.org/data/ docs/daac/icebridge/idbmg4/index.html). Surface ice gradients $(\nabla S)$ are calculated from the Greenland Ice Mapping Project (GIMP) digital elevation model (Howat et al., 2014). The flotation fraction was set to $f_{\mathrm{W}}=1$ (basal water pressures are equal to ice overburden pressure), which resulted in the maximum catchment area possible based on basal hydraulic gradients in this region.

Surface runoff in the SS catchment for 2012 was determined from bilinear interpolation of the $11 \mathrm{~km}$ grid resolution RACMO2.3 runoff values (3 grid cells within SS catchment) (Van den Broeke et al., 2009) to the $1 \mathrm{~km}$ grid from BMB2013 and the $150 \mathrm{~m}$ grid from MBM2014 (Fig. 7a). Portions of the catchment lower than $400 \mathrm{~m}$ a.s.l. were prescribed the same runoff values as the RACMO2.3 grid point within the catchment at $432 \mathrm{ma}$ a.s.1. $\left(68.82^{\circ} \mathrm{N}, 50.19^{\circ} \mathrm{W}\right)$ (Fig. 7a), as there are no RACMO2.3 grid points at lower elevations within the catchment. We assume that the ice-sheet bed is impermeable (does not store water) over the timescales considered here, and that all surface runoff is transferred immediately to the bed directly beneath the location of runoff formation at the ice sheet surface. 

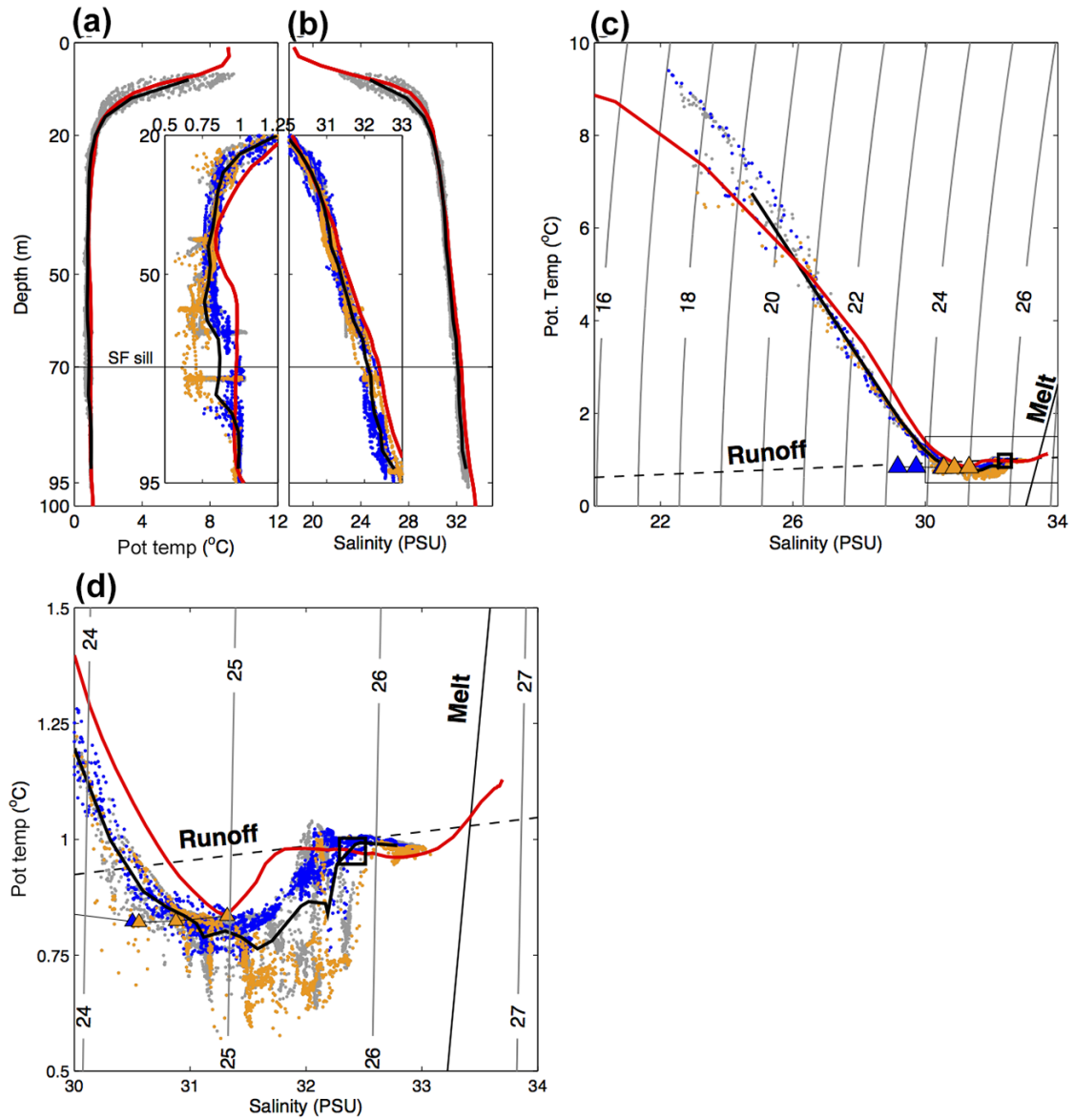

Figure 5. Glacially modified water in Sarqardleq Fjord. $\theta\left({ }^{\circ} \mathrm{C}\right)(\mathbf{a})$ and $S$ (b) profiles for R4 and R5 measurements over the full water-column depth (grey), with the average of R4 and R5 measurements and the ambient fjord waters in black and red, respectively. (a) and (b) insets show same data from 20-95 m depth over a finer $\theta$ or $S$ range, with measurements taken within the GMW1 and GMW2 regions along R4 and R5 (Fig. 3) shown in blue and gold, respectively. $\theta / S$ plots of R4 and R5 measurements (c) (colors same as in a and b), with melt and runoff mixing lines. Intersection for melt and runoff mixing lines set to CTD2 properties at grounding line depth (Fig. 6b). Black square along ambient fjord water profile shows $\theta / S$ properties at sill depth $(70 \mathrm{~m}) . \theta / S$ results for the Jenkins (2011) plume modeling (Table 4$)$ of D1 (blue triangles) and D2 (gold triangles) shown. (d) Same data as in (c) over finer $\theta / S$ range indicated by thin black box in (c).

\section{Results}

\subsection{Glacially modified water (GMW) temperature, salinity, and turbidity properties in Sarqardleq Fjord}

The summer Sarqardleq Fjord waters are characterized by a $\sim 10-20 \mathrm{~m}$ fresh and relatively warm surface layer overlying a thick layer of weakly stratified, relatively salty $(S=30.5-$ $32.5)$ and cold $\left(\theta \approx 1^{\circ} \mathrm{C}\right)$ waters (Table 2, Fig. 5a and b). The summer fjord waters are the same as the surface waters (SW) and Ilulissat Icefjord waters (IIW) observed by recent hydrographic surveys throughout Ilulissat Icefjord (Gladish et al., 2015a, b). SW are a mixture of IIW and fresher, warmer waters originating from local freshwater sources and warmed by summer atmospheric forcing. IIW originates from Arctic Waters observed in Disko and Baffin Bays (Gladish et al., 2015b) that enter SF after crossing sills at the mouth of JI Fjord (Schumann et al., 2012), the confluence of JI Fjord and Tasiussaq Fjord (Gladish et al., 2015a), and the mouth of SF (Fig. 1). These summer fjord waters are observed in the outer SF by a set of far-field CTD profiles taken near the fjord mouth more than $10 \mathrm{~km}$ from the SS terminus (triangles in Fig. 7a). We define ambient fjord waters as the average of these far-field CTD profiles (red profile in Figs. 5 and 6).

Near the glacier we observe a range of water masses not found in the outer fjord. These waters are generally colder, fresher, and more turbid than waters near the mouth of the fjord (Fig. 5a and b). The REMUS sections reveal two distinct glacially modified waters (GMWs), which we refer to as GMW1 and GMW2 (Fig. 4, Table 2). GMW1 and GMW2 are cold anomalies with a high turbidity signal that are most evident at two distinct locations (Fig. 4). GMW1 is observed in the southwestern ends of R1-R5 at $\sim 40 \mathrm{~m}$ depth, while 
Table 2. Water mass properties in Sarqardleq Fjord.

\begin{tabular}{lllll}
\hline Water mass & $\begin{array}{l}\text { Surface } \\
\text { Water } \\
(\mathrm{SW})\end{array}$ & $\begin{array}{l}\text { Ilulissat Icefjord } \\
\text { Waters (IIW) }\end{array}$ & $\begin{array}{l}\text { Glacially } \\
\text { Modified Water 1 } \\
(\text { GMW1) }\end{array}$ & $\begin{array}{l}\text { Glacially } \\
\text { Modified Water 2 } \\
\text { (GMW2) }\end{array}$ \\
\hline $\begin{array}{l}\text { Depth range }(\mathrm{m}) \\
S(\mathrm{PSU})\end{array}$ & $0-20$ & $20-$ SF bottom & $35-60$ & $50-70$ \\
$\theta\left({ }^{\circ} \mathrm{C}\right)$ & $21-30.5$ & $32.5-33.5$ & $30.8-31.5$ & $31.1-32.3$ \\
$\sigma_{\theta}\left(\rho_{\theta}-1000 \mathrm{~kg} \mathrm{~m}^{-3}\right)$ & $1.5-10$ & $0.8-1.5$ & $0.75-0.85$ & $0.59-0.75$ \\
Turbidity (NTU) & $16.0-24.3$ & $25.9-26.7$ & $24.6-25.1$ & $24.8-25.8$ \\
Origin/formation & Low $(<4$ NTU) & Low $(<4$ NTU) & High $(>9$ NTU) & High $(>9$ NTU) \\
\hline
\end{tabular}

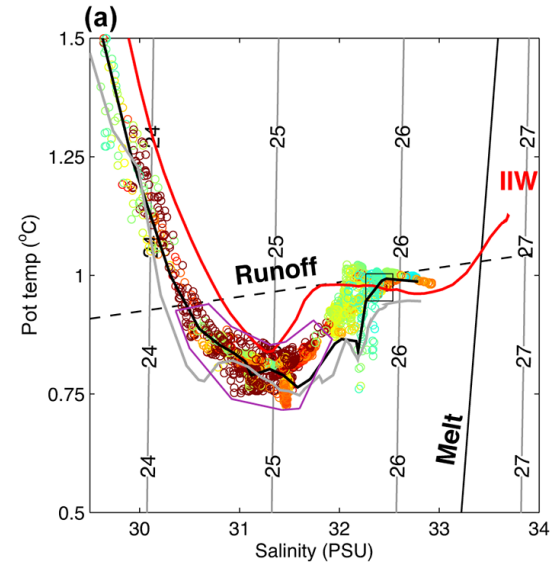

(b)

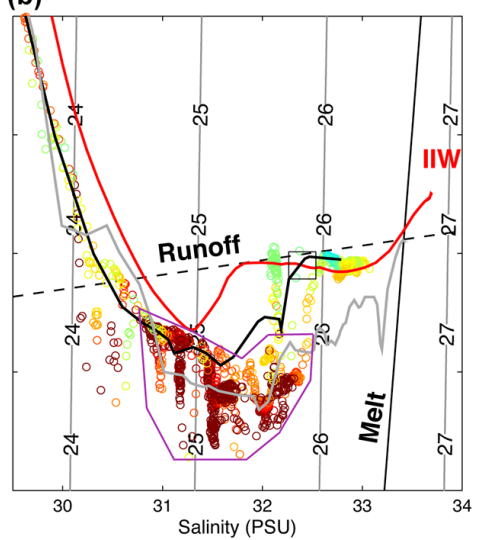

(c)

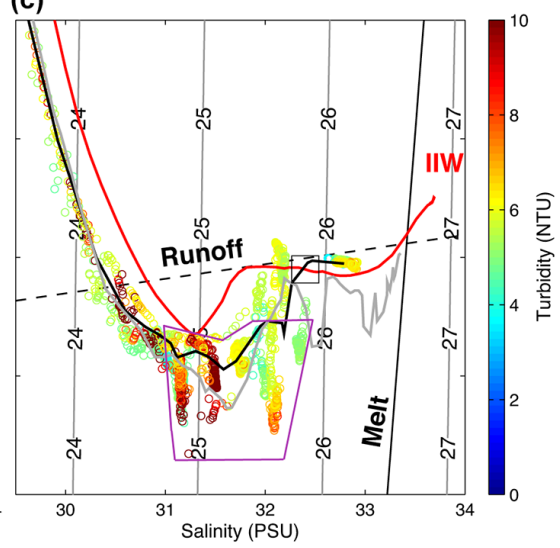

Figure 6. Turbidity of glacially modified waters. $\theta\left({ }^{\circ} \mathrm{C}\right)$ and $S$ (PSU) profiles from the regions along R4 and R5 outlined in blue (GMW1 region) (a), gold (GMW2 region) (b), and white (the region between GMW1 and GMW2) (c) in Fig. 3, with turbidity plotted as the color of the point. CTD1 (a), CTD2 (b), and CTD3 (c) are plotted in grey. The GMW region in $\theta / S$ space is outlined in purple. The average of all R4 and R5 measurements and the ambient fjord waters are plotted in black and red, respectively. Black square along ambient fjord water profile shows $\theta / S$ properties at sill depth $(70 \mathrm{~m})$.

GMW2 is observed in the northeastern ends of R1-R5 at $\sim 60 \mathrm{~m}$ depth (Fig. 4). Both GMW1's and GMW2's temperature and turbidity anomalies are most pronounced close to the glacier (Fig. $4 \mathrm{a}-\mathrm{c}$ ), and decrease as these waters spread away from the glacier (Fig. 4g-i). For example, the high turbidity associated with GMW1 spreads laterally beneath the pycnocline at R1 (Fig. 4i). Turbidity does not consistently map onto regions of local temperature minima; there are regions in the REMUS sections with high turbidity but with temperatures above $0.9^{\circ} \mathrm{C}$ (northeastern R1 below $80 \mathrm{~m}$ depth, Fig. 4i). High turbidity in these regions may be due to other sources including suspended sediment sourced from proglacial streams that enter SF as surface runoff near the northeastern end of R1 (Fig. 3) or iceberg discharge.

CTD casts 1-3 were taken closer to the SS face than the R5 transect during the same July 2012 field campaign (Fig. 3), and provide additional $\theta / S$ characteristics below the $100 \mathrm{~m}$ REMUS depth limit (Fig. 6a-c). These casts record deeper cold anomalies at the bottom of SF, as well as cold excursions from $\sim 40$ to $80 \mathrm{~m}$ depth, similar to REMUS measure- ments (Fig. 6a-c). Overall the CTD profiles align well with REMUS measurements where coincident (above $100 \mathrm{~m}$ ).

Further insight into the origins of GMW1 and GMW2 is found in $\theta / S$ space, where GMW1 and GMW2 stand out as cold anomalies as compared to waters near the mouth of the fjord (Figs. 5d and 6a, b). GMW1 and GMW2 are clustered at two distinct densities (Fig. 6a and b). At a density of $\sigma_{\theta} \approx 24.8 \mathrm{~kg} \mathrm{~m}^{-3}$, where $\sigma_{\theta}$ is potential density less $1000 \mathrm{~kg} \mathrm{~m}^{-3}$, GMW1 is lighter than GMW2 $\left(\sigma_{\theta} \approx 25.5 \mathrm{~kg} \mathrm{~m}^{-3}\right)$ (Table 2, Fig. $6 \mathrm{a}$ and b). In general, GMW is fresher and more turbid compared to ambient waters, consistent with fjord waters mixing with submarine melt and subglacial discharge. If we assume that both GMW1 and GMW2 are driven by subglacial discharge plumes that emerged at the grounding line, then we can assume that the bulk of the entrainment was of deeper waters at densities of $\sigma_{\theta}=25.5-26.5 \mathrm{~kg} \mathrm{~m}^{-3}$ (Fig. 6a and b). In $\theta / S$ space, GMW is further identified with the use of meltwater and runoff mixing lines (Figs. 5c, d and 6a-c), which represent conservative mixing between ambient water and submarine melt or subglacial discharge, respectively (Jenkins, 1999). End- 

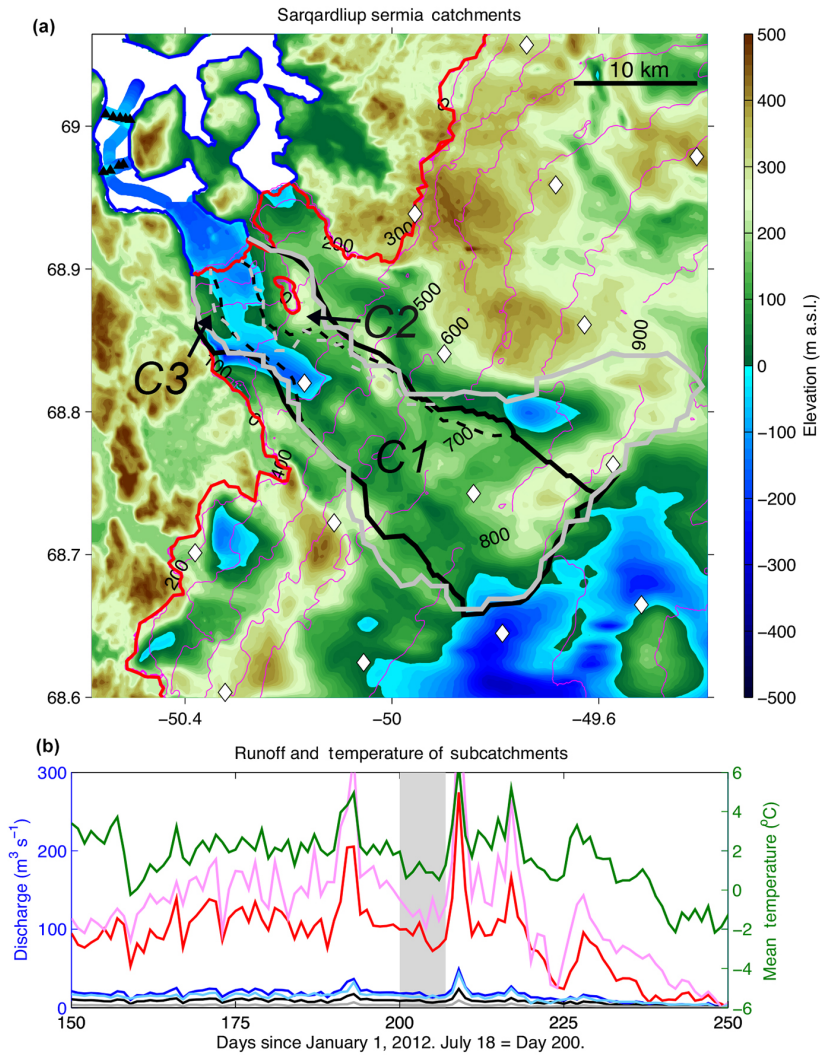

Figure 7. Saqqarliup sermia catchments and discharge. (a) Estimated Saqqarliup sermia catchment (thick black line) and subcatchments C1, C2, and C3 (dashed black line) from the MBM2014 analysis over Morlighem et al. (2014) bedrock elevation map (filled contours) and ice sheet surface (magenta contours). BBM2013 catchment and subcatchments outlines in thick solid and dashed grey lines, respectively. Ice sheet margin and coastlines shown in red and blue, respectively. RACMO2.3 $11 \mathrm{~km}$ resolution grid points shown with white diamonds. Sarqardleq Fjord bathymetry and outer Sarqardleq Fjord CTD positions (black triangles) and depth measurements also shown. (b) Daily C1, C2, and C3 subcatchment MBM2014 RACMO2.3 discharge estimates (red, blue, and black lines, respectively) and daily average RACMO2.3 temperature (green line) across the Saqqarliup sermia subcatchment C1 for DOY 150-250, 2012. Daily C1, C2, and C3 subcatchment BBM2013 RACMO2.3 discharge estimates in pink, cyan, and grey lines, respectively. Dates of REMUS and CTD sampling from DOY 200-207 marked by grey bar.

points for the melt and runoff mixing lines are set to properties observed by CTD cast 2 at grounding line depth (Figs. 3 and 6b). GMW1 and GMW2 are consistent with the transformation of ambient waters by mixing with submarine melt and subglacial discharge, as they fall between the meltwater and runoff mixing lines in $\theta / S$ space (Figs. 5c, d and $6 a-c)$.

Thus, near the glacier we observe water masses not found in the outer fjord that we attribute to glacier-ocean interactions (Jenkins et al., 2010; Straneo et al., 2011). We observe two distinct GMW that are both colder, fresher, and more turbid compared to ambient waters at similar depths (Figs. 5a-c, and 6a, b) but are located in different regions of the fjord (Fig. 3). GMW1, observed in the southwestern ends of R1-R5, is considerably fresher and lighter than the colder GMW2 observed in the northeastern ends of R1-R5 (Figs. 3 and 6a, b, Table 2). The lighter GMW1 $\left(\sigma_{\theta} \approx 24.8\right)$ is observed at an equilibrium depth of $35-60 \mathrm{~m}$, while the denser GMW2 $\left(\sigma_{\theta} \approx 25.5\right)$ has a deeper equilibrium depth of 50-70 m (Table 2), suggesting that GMW1 contains a higher fraction of subglacial runoff than GMW2 (see Sect. 4.3). We further elucidate GMW1 and GMW2 origins in the following section on the SS catchment and subglacial discharge across the SS terminus.

\subsection{SS catchment and subglacial discharge across SS terminus}

The $400 \pm 50 \mathrm{~km}^{2}$ area SS catchment extends $15 \mathrm{~km}$ up the basal valley beneath the $6 \mathrm{~km}$-wide SS outlet glacier snout and widens under inland ice, reaching a maximum inland extent of $35 \mathrm{~km}$ just above the $900 \mathrm{~m}$ a.s.1. ice-sheet surface elevation contour (Fig. 7a, Table 3). Bedrock basins that steer subglacial water to the southwest delineate the southern boundary of the catchment (Fig. 7a). The northern extent of the catchment is bounded by the Alanngorliup sermia outlet glacier catchment parallel to SS (Fig. 7a). Three subcatchments $-\mathrm{C} 1, \mathrm{C} 2$, and $\mathrm{C} 3$ - are delineated within the SS catchment from binning $-\nabla \Phi_{\mathrm{h}}$ streamline endpoints along the SS face in both the MBM2014 and BBM2013 analyses (Fig. 7a). The main difference between the MBM2014 and BBM2013 analyses is the size of the $\mathrm{C} 1$ subcatchment (BBM2013 33\% larger), with the BBM2013 analysis delineating the northern inland extent of $\mathrm{C} 1$ into a region the MBM2014 analysis places in the Alanngorliup sermia catchment (Figs. 1 and 7a, Table 3).

The three sub-catchments delineate three sections along the terminus (Fig. 7a), with each section mapping onto a directly observed or inferred subglacial meltwater discharge channel (D1, D2, and D3 in Fig. 3). Subcatchment C1, the largest sub-catchment at $269 \mathrm{~km}^{2}$ area (MBM2014) discharges along the middle of the terminus at discharge location D1, while subcatchment $\mathrm{C} 2$ and $\mathrm{C} 3$ discharge along the northeastern and southwestern extents of the terminus at D2 and D3, respectively (Fig. 3). D1 and D2 align with two distinct bathymetric troughs of 150 and $132 \mathrm{~m}$ depth, respectively (Table 3), bounded by bathymetry highs of 60 to $40 \mathrm{~m}$ depth in SF (Fig. 3). D1 and D2 also coincide with depressed glacier margin heights along the terminus, enhanced ice sheet velocities (Joughin et al., 2013), and high calving flux relative to the rest of the terminus. D1 is a particularly frequent calving region in comparison to the rest of the terminus, as observed during our two field campaigns. At times, a turbulent, sediment-rich plume reaches the fjord surface at D1, as observed in satellite images and during subsequent fieldwork in July 2013 (Mankoff et al., 2016). While exhibiting sim- 
Table 3. Saqqarliup sermia subcatchments and runoff estimates.

\begin{tabular}{|c|c|c|c|c|}
\hline Subcatchment & $\mathrm{C} 1$ & $\mathrm{C} 2$ & $\mathrm{C} 3$ & $\mathrm{SS}\left(\sum \mathrm{C} 1-3\right)$ \\
\hline Discharge location & D1 & D2 & D3 & - \\
\hline \multicolumn{5}{|c|}{ Bathymetry along catchment terminus } \\
\hline Average depth (m) & 116.4 & 101.5 & 39.9 & - \\
\hline Maximum depth (m) & 150.4 & 131.8 & 49.9 & - \\
\hline \multicolumn{5}{|c|}{ Morlighem et al. (2014) (MBM2014) } \\
\hline Catchment area $\left(\mathrm{km}^{2}\right)$ & 268.74 & 47.97 & 23.31 & 340.02 \\
\hline Catchment area compared to SS (\%) & $79 \%$ & $14 \%$ & $7 \%$ & - \\
\hline $\begin{array}{l}\text { Catchment average daily runoff July } \\
2012 \pm \sigma \mathrm{JULY} \\
\left(Q_{\mathrm{sg}}\right)\left(\mathrm{m}^{3} \mathrm{~s}^{-1}\right)\end{array}$ & $115.78 \pm 42.59$ & $20.62 \pm 7.33$ & $9.97 \pm 3.47$ & $146.37 \pm 53.26$ \\
\hline Average daily July runoff compared to SS (\%) & $79 \%$ & $14 \%$ & $7 \%$ & - \\
\hline $\begin{array}{l}\text { Catchment average daily runoff during } \\
\text { the field expedition (DOY 200, 203-206) } \\
\pm \sigma_{\mathrm{JULY}}\left(Q_{\mathrm{sg}}\right)\left(\mathrm{m}^{3} \mathrm{~s}^{-1}\right)\end{array}$ & $88.70 \pm 42.59$ & $16.10 \pm 7.33$ & $7.89 \pm 3.47$ & $112.69 \pm 53.26$ \\
\hline \multicolumn{5}{|c|}{ Bamber et al. (2013) (BBM2013) } \\
\hline Catchment area $\left(\mathrm{km}^{2}\right)$ & 402 & 42 & 9 & 453 \\
\hline Catchment area compared to SS (\%) & $89 \%$ & $9 \%$ & $2 \%$ & - \\
\hline $\begin{array}{l}\text { Catchment average daily runoff July } \\
2012 \pm \sigma \mathrm{JULY} \\
\left(Q_{\mathrm{sg}}\right)\left(\mathrm{m}^{3} \mathrm{~s}^{-1}\right)\end{array}$ & $171.01 \pm 64.27$ & $17.47 \pm 6.40$ & $3.72 \pm 1.36$ & $192.20 \pm 71.75$ \\
\hline Average daily July runoff compared to SS (\%) & $89 \%$ & $9 \%$ & $2 \%$ & - \\
\hline $\begin{array}{l}\text { Catchment average daily runoff during } \\
\text { the field expedition (DOY 200, 203-206) } \\
\pm \sigma_{\text {JULY }}\left(Q_{\text {sg }}\right)\left(\mathrm{m}^{3} \mathrm{~s}^{-1}\right)\end{array}$ & $122.83 \pm 64.27$ & $14.08 \pm 6.40$ & $3.05 \pm 1.36$ & $139.96 \pm 71.75$ \\
\hline
\end{tabular}

ilarly frequent calving, terminus height, and velocity characteristics as D1, surface plumes have not been observed at D2. Subcatchment C3 discharges beneath the slow-moving, southwestern margin of the terminus at D3 (Fig. 3), through a visible, broad channel mouth at the fjord surface, entering into a shallow region of SF (Table 3, Fig. 3).

Variability in calculated subglacial discharge for each subcatchment is controlled primarily by temperature variability, with daily runoff rates a summation of melt and precipitation across the catchment (Van den Broeke et al., 2009) (Fig. 7b, Table 3). During our 2012 field expedition, catchment runoff rates were slightly below the monthly July average, with no above average temperature days falling within the sampling period (Fig. 7b). Disregarding the possibility for periods of subglacial water storage during the enand subglacial transport of runoff to the SS terminus, daily discharge rates across the terminus during the field expedition are $146 \mathrm{~m}^{3} \mathrm{~s}^{-1}$ (MBM2014 estimate) (Table 3). An additional though likely minor amount of surface meltwater runoff enters the fjord through proglacial streams, which discharge at land-terminating margins abutting SS (Fig. 3). Daily runoff discharges for $\mathrm{C} 1$ and $\mathrm{C} 2$ scale primarily with area differences and are 115.78 and $20.62 \mathrm{~m}^{3} \mathrm{~s}^{-1}$, respectively (MBM2014) (Table 3). As error estimates for the RACMO2.3 runoff rates are not available, we take the stan- dard deviation of July 2012 daily discharge rates as a measure of the potential variation observed during the field expedition (Table 3).

\subsection{Buoyant plume model for the SS-SF system}

As described above, we have found evidence for three main subglacial catchments discharging runoff into SF at three locations along the terminus. The two prominent discharge locations, D1 and D2, coincide with GMW1 and GMW2 observations. The picture that emerges is that different properties of GMW1 and GMW2 are attributable to differences in subglacial discharge magnitude at that location. Here, we use a buoyant plume model to investigate the extent to which the two plumes' predicted characteristics compare with the GMW1 and GMW2 observations. Buoyant plume theory states that the growth of a plume is dictated by the plume's buoyancy forcing, which can be due to subglacial discharge at the grounding line and/or submarine melting along the terminus (Morton et al., 1956; Turner, 1979). The buoyancy forcing of the plume determines the plume's vertical velocity and entrainment of ambient fjord waters (Morton et al., 1956; Turner, 1979). A class of simple, one-dimensional buoyant plume models has been used to investigate plume dynamics and terminus melt rates near glaciers (Hellmer and Olbers, 1989; Jenkins, 1991, 2011). Solutions to these models es- 
Table 4. Buoyant plume model simulations for D1 and D2 scenarios at MBM2014 subglacial discharge values. Plume $\theta$ and $S$ ranges are plotted in Fig. 5c and d.

\begin{tabular}{lll}
\hline & D1 & D2 \\
\hline Ambient $\theta / S$ profile & CTD 1 & CTD 2 \\
Calving face depth $(\mathrm{m})$ & 153 & 140 \\
Subglacial discharge $\left(Q_{\mathrm{sg}}\right)\left(\mathrm{m}^{3} \mathrm{~s}^{-1}\right)$ & {$[46.11,88.70,131.29]$} & {$[8.77,16.10,23.43]$} \\
Plume $\theta\left({ }^{\circ} \mathrm{C}\right)$ at neutral buoyancy depth & {$[0.82,0.85,0.84]$} & {$[0.83,0.82,0.82]$} \\
Plume $S(\mathrm{PSU})$ at neutral buoyancy depth & {$[30.50,29.72,29.17]$} & {$[31.32,30.88,30.56]$} \\
Plume $\sigma_{\theta}\left(\rho_{\theta}-1000 \mathrm{~kg} \mathrm{~m}^{-3}\right)$ at neutral buoyancy depth & {$[24.34,23.74,23.30]$} & {$[24.90,24.59,24.35]$} \\
Neutral buoyancy depth $(\mathrm{m})$ & {$[21.79,14.03,13.79]$} & {$[41.41,31.23,27.68]$} \\
Volume fraction of entrained water & {$[0.94,0.94,0.94]$} & {$[0.96,0.96,0.96]$} \\
\hline
\end{tabular}

timate plume temperature, salinity, vertical velocity, width, and intrusion depth, the depth at which the plume becomes neutrally buoyant and changes from flowing vertically up the terminus to flowing horizontally away from the terminus. Here we investigate D1 and D2 plume scenarios using the Jenkins (2011) buoyant plume model adapted to a halfconical plume driven by a point-source.

The plume model uses conservation of the fluxes of mass, momentum, heat, and salt, to calculate plume characteristics that are uniform in time and across-flow direction (Jenkins, 2011). Key initial conditions that we prescribe include an ice temperature of $-10^{\circ} \mathrm{C}$ (Lüthi et al., 2002); fjord ambient temperature and stratification (Table 4); a vertical glacier face; and a modeled subglacial discharge across the terminus, $Q_{\text {sg }}$ (Table 4). Entrainment of ambient fjord waters into the buoyant plume is modeled as a product of plume velocity, the sine of the ice terminus slope (vertical for SS), and a theoretically defined entrainment coefficient $\left(E_{0}\right)$ of 0.08 following Sciascia et al. (2013).

The buoyant plume model is calculated for D1 and D2 scenarios and evaluated based on end plume temperature, salinity, and intrusion depth (Table 4). Ambient water properties are defined by two CTD measurements of full water column temperature and salinity from nearby D1 and D2 (CTD1 and CTD2, respectively, in Fig. 3). Temperature, salinity, and intrusion depth at the end of the plume are found to be largely insensitive to varying ambient fjord water properties if the ambient waters show strong summer stratification. We use the RACMO2.3-derived estimates of subglacial discharge across the terminus at D1 and D2 $\left(\mathrm{m}^{3} \mathrm{~s}^{-1}\right.$ ) (using MBM2014 of average daily runoff during the field expedition; $\mathrm{m}^{3} \mathrm{~s}^{-1}$ ) (Table 3).

Given the observed ocean stratification and the modeled subglacial discharge, the plume model confirms that GMW1 should be notably fresher and lighter than GMW2 (Fig. 5c, Table 4). This supports the conclusion that GMW1 and GMW2 are the result of two distinct discharge locations with different subglacial discharge magnitudes. For the D2 scenario, the plume model predicts end plume properties and neutrally buoyant depths $(\sim 31 \mathrm{~m})$ that are aligned with the
GMW2 observations at similar depths (Fig. 5c and d). For the D1 scenario, the plume model predicts end plume properties that are lighter and fresher than the observed GMW1 (Fig. 5c, Tables 2 and 4). The predicted D1 plume would reach above the $20 \mathrm{~m}$-deep pycnocline at neutral buoyancy depth of $\sim 14 \mathrm{~m}$ (Table 4 ). With a minimum amount of overshoot, we might expect the D1 plume to reach the surface or depths close enough to the surface to be visible during field observations. In reality, the plume at D1 was not observed to reach the surface, and GMW1 was only observed beneath the pycnocline (Fig. 4). There are several possible reasons for this discrepancy. First, the plume model may have an incorrect entrainment parameterization. Second, the estimated subglacial discharge could be incorrect. In addition, after detaching from the terminus at the plume's intrusion depth, GMW spreads an additional $150 \mathrm{~m}$ away from the SS face before being observed at R5. Over this time, we would expect lateral mixing to further dilute the GMW properties. The plume model does not describe lateral mixing, as the model ends when the plume reaches intrusion depth.

\section{Discussion}

\subsection{Subglacial catchments, discharge, and GMW observations}

Our analysis of the ocean data and subglacial catchments both suggest that there are two primary subglacial discharge locations along the ice-ocean interface. On the outlet glacier catchment side of the interface, the primary subcatchments, $\mathrm{C} 1$ and C2 (Fig. 7a), route substantial ( $>90 \%$ ) of the total SS meltwater runoff (Table 3 ) into the fjord across the grounding line at discharge locations D1 and D2, respectively (Fig. 3). On the ocean side of the interface, GMW1 and GMW2 are located near D1 and D2, respectively, and show fresher, colder waters with high turbidity as compared to ambient fjord waters (Fig. 5a and b). The properties of these waters, in particular, are consistent with glacial modification due to significant injection of runoff at depth as is expected from a localized discharge of meltwater at D1 and 
D2. Finally, between D1 and D2, there is a $2 \mathrm{~km}$ stretch of the terminus where GMW show cold excursions with low to high turbidity along R4 and R5 (Fig. 6c). The formation of this GMW is less clear, though in this region between subglacial discharge locations, GMW properties are more indicative of submarine melt and limited subglacial discharge and/or lateral mixing of GMW1 and GMW2.

Although we lack observations within the plumes themselves in 2012, the ocean observations of GMW suggest that these waters are produced by ambient fjord waters interacting with a limited number of discrete plumes along the terminus. Our observations of GMW beneath the pycnocline at a distance of $\sim 150 \mathrm{~m}$ from the terminus suggest that the two plumes reach neutral buoyancy beneath the fjord surface. Visual observations during the 2012 field campaign confirm that the plumes did not reach the fjord surface during this time. In contrast, during the July 2013 field campaign at SF, a vigorous, turbulent plume was observed to break through at the fjord surface at D1 (Mankoff et al., 2016).

Differences in subglacial discharge magnitude entering the fjord at D1 and D2 is both observed and predicted to result in water mass differences between GMW1 and GMW2. Fed by subglacial discharge from the largest subglacial subcatchment, GMW1 is fresher and lighter than GMW2 (Table 3, Figs. 5a-d and $6 a, b)$. D2 receives roughly $20 \%$ of the subglacial discharge magnitude at D1 (Table 3). This smaller subglacial discharge results in a relatively saltier and heavier GMW2 in comparison to GMW1 (Figs. 5a-d and 6a, b). While a greater volume of subglacial discharge leads to a fresher water mass, the strength of the resultant buoyant plume also plays a role in near-ice water mass transformation. Plume theory predicts that a plume fed by a greater amount of subglacial discharge will have a stronger buoyancy forcing, leading to both faster entrainment of ambient waters and an increase in the fraction of subglacial discharge in the plume (Jenkins, 2011; Straneo and Cenedese, 2015). In this fjord, the entrainment of ambient waters into a plume results in GMW with temperatures and salinities that are warmer and saltier than the subglacial discharge entering the fjord $\left(\theta=0^{\circ} \mathrm{C}, S=0 \mathrm{PSU}\right)$. The volume fraction of entrained water for both D1 and D2 plumes is above 0.9 (Table 4), indicating that for this fjord, the plume temperature and salinity at neutral buoyancy depth are largely a function of the entrained ambient water mass. Thus, overall, the greater subglacial discharge at D1 drives a more vigorous plume that mixes with both IIW and SW, which results in GMW that is closer in $\theta$ and $S$ to SW than IIW (Table 2, Fig. 6a). In contrast, smaller subglacial discharge at D2 drives a less vigorous plume that mixes at deeper depths with only IIW, resulting in GMW that retains the cold signature of subglacial discharge and submarine melting (Table 2, Fig. 6b).

Consistent with the ocean data, the plume model predicts end plume conditions at D1 are fresher and lighter than those at D2 as they contain a greater amount of subglacial dis- charge (Fig. 5d, Table 4). However, the end plume conditions from the Jenkins (2011) model for D1 scenarios are lighter than the GMW1 we observe (Fig. 5c, Table 4). In addition to errors in the plume model and subglacial discharge estimates, lateral mixing within $\sim 150 \mathrm{~m}$ of the terminus is a consideration for comparing the plume model results and observed GMW. Large amounts of mixing with ambient waters likely occur once the plume detaches from the terminus and GMW is exported away from the ice-ocean interface. This lateral mixing has been observed in other marine terminating outlet glacier systems in Greenland, where GMW from an inferred localized subglacial discharge location was found uniformly across the fjord in profiles taken $\sim 200 \mathrm{~m}$ from the terminus (Chauché et al., 2014).

\subsection{Observing the heterogeneous near-ice environment}

The coupling of near-ice observations and subglacial discharge routing is necessary for understanding ice-ocean interactions at marine terminating outlet glaciers. While multiple recent studies have observed GMW in fjords (Chauché et al., 2014; Inall et al., 2014; Johnson et al., 2011; Mortensen et al., 2011; Straneo et al., 2011; Sutherland et al., 2014) and others have measured and modeled runoff based on surface catchment area (Mernild et al., 2015), no studies have directly linked the two sides of this interface or considered the role of basal routing on catchment area. For this study, we pair near-ice observations and subglacial discharge routing to show for the first time that the observed GMW characteristics align with the subglacial discharge magnitudes from outlet glacier subcatchments.

Our results highlight the necessity of subsurface observations within the near-ice zone for accurately characterizing the heterogeneous processes at the ice-ocean interface. We observe heterogeneous, subsurface GMW as high turbidity, cold excursions in across-fjord sections as far as $1.5 \mathrm{~km}$ from the SS terminus (Fig. 4). Further away from the terminus, only the cold excursion at the density of GMW1 remains in the far-field profiles (Fig. 5d). Thus, while in the near-ice zone there are multiple subglacial discharge locations across the SS grounding line and different types of GMW observed, only a modified GMW1 is identifiable in far-field profiles. Noble gas observations of GMW in neighboring Greenland fjords observe a dilution of GMW as you move away from the terminus, suggesting that GMW is highly diluted outside of the near-ice zone (Beaird et al., 2015). Thus, the fact that only a modified GMW1 is detectable in the far-field profiles is likely due to the larger volume flux of discharge from D1 entering the fjord as compared to discharge from D2 (Table 4). Sill depth may be an additional factor impeding the export of GMW2; GMW2 is observed at or barely above the $70 \mathrm{~m}$ sill depth, while GMW1 is observed at shallower depths (Figs. 1 and 3, Table 2). The implication is that far-field measurements only provide a partial representation of processes along the ice-ocean interface. 
Similar to the single cold excursion observed in the ambient SF waters, many studies have observed evidence of subsurface GMW uniformly distributed across fjord width outside of the near-ice zone (Johnson et al., 2011; Mortensen et al., 2011; Straneo et al., 2011; Chauché et al., 2014; Inall et al., 2014; Sutherland et al., 2014). Observations at Store and Rink glaciers as close as $\sim 200 \mathrm{~m}$ to termini identify one to a couple of surface and subsurface plumes along each glacier termini (Chauché et al., 2014). However, the GMW observed $200 \mathrm{~m}$ from the termini is uniform across the fjord (Chauché et al., 2014). While our observations of subglacial discharge locations in SF are consistent with the low number of subglacial discharge locations found at Store and Rink glaciers (Chauché et al., 2014), we are able to further differentiate and map types of GMW to outlet glacier subcatchments.

The subsurface nature of the plumes and resultant GMW we observed is consistent with multiple studies that have also observed subsurface GMW (Chauché et al., 2014; Inall et al., 2014; Johnson et al., 2011; Mortensen et al., 2011; Straneo et al., 2011; Sutherland et al., 2014). Together these findings drive home the point that plumes and other processes at the ice-ocean interface actively driving submarine melt can and often do operate without creating an expression on the fjord surface. Surface expressions of plumes have been detected at many Greenland tidewater glaciers and invoked as evidence for runoff release from the ice sheet into fjords and proglacial streams (Chu et al., 2009; Tedstone and Arnold, 2012), and have even been proposed as a potentially useful remote measure of runoff variability (Chu et al., 2012). However, our observations of plumes and GMW that reach neutral buoyancy beneath the pycnocline suggest in many cases this relationship does not hold true. The magnitude of subglacial discharge entering a fjord, fjord stratification, and fjord depth have all been shown to affect whether a plume reaches the surface (Sciascia et al., 2013). The absence of plume surface expression does not negate the presence of subglacial discharge plumes that may be driving significant submarine melt and circulation along a tidewater terminus. Thus, across-fjord subsurface observations within the nearice zone provide the most comprehensive characterization of ice-ocean interactions in Greenland fjords.

\subsection{Observational constraints for modeling the heterogeneous near-ice environment}

While spatial distribution of subglacial discharge is a critical component for estimating submarine melt rates at marine terminating outlet glaciers in numerical models (Slater et al., 2015), we have few observations to constrain subglacial discharge scenarios. Model configurations of subglacial discharge for major Greenland outlet glaciers range from a distributed subglacial system where equal amounts of subglacial discharge emerge across the entire grounding line width (Jenkins, 2011; Sciascia et al., 2013), to partitioning subglacial discharge between a number of equally spaced plumes along the terminus (Kimura et al., 2014; Slater et al., 2015), to routing all subglacial discharge through a single subglacial channel emerging in one, central plume (Slater et al., 2015; Xu et al., 2013). While all these models, which share the same melt parameterization, agree that submarine melt rates increase with increasing subglacial discharge (Jenkins, 2011; Kimura et al., 2014; Sciascia et al., 2013; Slater et al., 2015; Xu et al., 2012, 2013), the amount and distribution of the increased melting depends on the largely unknown pattern of subglacial discharge (Straneo and Cenedese, 2015). Most recently, Slater et al. (2015) concluded that a distributed system yields as much as 5 times more submarine melting than a channelized system consisting of a few plumes along the terminus. Thus, spatial distribution of subglacial melt is critically important for accurately estimating submarine melt rates in a numerical model (Slater et al., 2015; Straneo and Cenedese, 2015).

For this system, we observe at least two, localized areas of subglacial discharge separated by wide areas of the terminus with little to no subglacial discharge. Our survey interval was limited to peak summer conditions, when one would expect channelized subglacial discharge. Observations during other times of the year, in particular prior to and during the onset of meltwater runoff early in the melt season, as well as towards the end of the melt season when runoff is reduced again, would be useful to more fully characterize the seasonally evolving magnitude and type of subglacial discharge in this environment. A simple subglacial meltwater routing model using MBM2014, the GIMP ice sheet surface digital elevation model, and RACMO2.3 runoff estimates was able to predict the number, approximate location, and relative magnitude and type of subglacial discharge locations. And while this subglacial catchment delineation method should be supplemented with ocean measurements and field observations where possible, in many cases it may prove a useful first-order approximation of the spatial distribution of subglacial discharge at other marine terminating outlet glaciers where fjord observations are lacking or difficult to obtain.

\section{Conclusions}

Hydrographic surveys completed by an AUV in Sarqardleq Fjord provide several new observational insights to the characteristics and distribution of near-ice GMW in a shallowsilled, moderate-sized west Greenland fjord. Overcoming navigation difficulties in the acoustically noisy, iceberg-filled fjord, the AUV covered a large portion of the near-ice waters along the terminus. AUV observations provide the most comprehensive and spatiotemporally detailed snapshots of across-fjord hydrography in the near-ice zone to date. From these measurements we identified two types of GMW that map onto two plumes based on $\theta / S /$ turbidity near-ice properties and subcatchment runoff estimates. The two plumes are, notably, not observed to reach the surface in the fjords, but at- 
tain neutral buoyancy beneath the pycnocline of the strongly stratified summer fjord conditions.

Our observations detail how mixing processes at the iceocean interface driven by either submarine melting and/or plumes fed by subglacial discharge can produce GMW that is colder, fresher, and at times more turbid than ambient fjord waters. An idealized plume model for plumes fed by a range of RACMO2.3-derived subglacial discharges appropriate for the two plumes observed in this fjord is qualitatively consistent with the largest subglacial discharge being associated with the lighter, fresher glacially modified water mass. The characterization of GMW and subglacial catchments for this outlet glacier system provides critical observational constraints on the widely varying subglacial discharge scenarios employed by the current set of submarine melt modeling studies. Results supply near-ice observations abutting one Greenland Ice Sheet outlet glacier, though the continued investigation of other Greenland outlet glaciers is much needed to ultimately move towards an accurate representation of oceanic forcing at outlet glacier termini and an improved understanding of the ice sheet's outlet glacier dynamics.

Author contributions. F. Straneo, S. B. Das, and A. J. Plueddemann conceived the study. F. Straneo, S. B. Das, and A.L.K. performed the fieldwork. A. J. Plueddemann, A. L. Kukulya, and L. A. Stevens processed the REMUS data. L. A. Stevens, F. Straneo, S. B. Das, and A. J. Plueddemann analyzed the REMUS and CTD data. L. A. Stevens created the bathymetry map. M. Morlighem provided the reprocessed bedrock elevation map. L. A. Stevens, F. Straneo, S. B. Das, and A. J. Plueddemann interpreted the results. L. A. Stevens wrote the paper. All authors commented on the paper.

Acknowledgements. Support was provided by the National Science Foundation's Office of Polar Programs (NSF-OPP) through PLR-1418256 to F. Straneo, S. B. Das and A. J. Plueddemann, PLR-1023364 to S. B. Das, and through the Woods Hole Oceanographic Institution Ocean and Climate Change Institute Arctic Research Initiative to F. Straneo, S. B. Das, and A. J. Plueddemann. L. A. Stevens was also supported by a National Science Foundation Graduate Research Fellowship. S. B. Das was also supported by the Woods Hole Oceanographic Institution James E. and Barbara V. Moltz Research Fellowship. M. Morlighem was supported by the National Aeronautics and Space Administration's (NASA) Cryospheric Sciences Program through NNX15AD55G. The authors would like to acknowledge Michiel van den Broeke for providing RACMO output; Jeff Pietro and John Kemp of the WHOI Mooring Operations, Engineering and Field Support Group, and Rebecca H. Jackson and Ove Villadsen for their help during the 2012 field operations; Clark Richards for guidance using the Barnes Objective Analysis; Kenneth D. Mankoff for conversations on plumes in Sarqardleq Fjord; Nicholas L. Beaird for conversations on glacially modified waters in Greenland fjords; and Adrian Jenkins and Claudia Cenedese for providing the plume model code and discussing its application.
The authors declare no competing financial interests.

Edited by: G. H. Gudmundsson

\section{References}

Andrews, L. C., Catania, G. A., Hoffman, M. J., Gulley, J. D., Lüthi, M. P., Ryser, C., Hawley, R. L., and Neumann, T. A.: Direct observations of evolving subglacial drainage beneath the Greenland Ice Sheet, Nature, 514, 80-83, doi:10.1038/nature13796, 2014.

Bamber, J., van den Broeke, M., Ettema, J., Lenaerts, J., and Rignot, E.: Recent large increases in freshwater fluxes from Greenland into the North Atlantic, Geophys. Res. Lett., 39, 1-4, doi:10.1029/2012GL052552, 2012.

Bamber, J. L., Griggs, J. A., Hurkmans, R. T. W. L., Dowdeswell, J. A., Gogineni, S. P., Howat, I., Mouginot, J., Paden, J., Palmer, S., Rignot, E., and Steinhage, D.: A new bed elevation dataset for Greenland, The Cryosphere, 7, 499-510, doi:10.5194/tc-7499-2013, 2013.

Banwell, A. F., Willis, I. C., and Arnold, N. S.: Modeling subglacial water routing at Paakitsoq, W Greenland, J. Geophys.Res. Earth, 118, 1282-1295, doi:10.1002/jgrf.20093, 2013.

Barnes, S. L.: Applications of the Barnes Objective Analysis Scheme. Part I: Effects of Undersampling, Wave Position, and Station Randomness, J. Atmos. Ocean. Tech., 11, 1433-1448, 1994.

Beaird, N., Straneo, F., and Jenkins, W.: Spreading of Greenland meltwaters in the ocean revealed by noble gases, Geophys. Res. Lett., 42, 7705-7713, doi:10.1002/2015GL065003, 2015.

Box, J. E., Yang, L., Bromwich, D. H., and Bai, L.-S.: Greenland Ice Sheet Surface Air Temperature Variability: 1840-2007, J. Climate, 22, 4029-4049, doi:10.1175/2009JCLI2816.1, 2009.

Carroll, D., Sutherland, D. A., Shroyer, E. L., Nash, J. D., Catania, G. A., and Stearns, L. A.: Modeling Turbulent Subglacial Meltwater Plumes: Implications for Fjord-Scale Buoyancy-Driven Circulation, J. Phys. Oceanogr., 45, 21692185, doi:10.1175/JPO-D-15-0033, 2015.

Chandler, D. M., Wadham, J. L., Lis, G. P., Cowton, T., Sole, A., Bartholomew, I., Telling, J., Nienow, P., Bagshaw, E. B., Mair, D., Vinen, S., and Hubbard, A.: Evolution of the subglacial drainage system beneath the Greenland Ice Sheet revealed by tracers, Nat. Geosci., 6, 1-4, 2013.

Chauché, N., Hubbard, A., Gascard, J. C., Box, J. E., Bates, R., Koppes, M., Sole, A., Christoffersen, P., and Patton, H.: Iceocean interaction and calving front morphology at two west Greenland tidewater outlet glaciers, The Cryosphere, 8, 14571468, doi:10.5194/tc-8-1457-2014, 2014.

Chu, V. W., Smith, L. C., Rennermalm, A. K., Forster, R. R., Box, J. E., and Reehy, N.: Sediment plume response to surface melting and supraglacial lake drainages on the Greenland ice sheet, J. Glaciol., 55, 1072-1082, doi:10.3189/002214309790794904, 2009.

Chu, V. W., Smith, L. C., Rennermalm, A. K., Forster, R. R., and Box, J. E.: Hydrologic controls on coastal suspended sediment plumes around the Greenland Ice Sheet, The Cryosphere, 6, 119, doi:10.5194/tc-6-1-2012, 2012.

Cuffey, K. M. and Patterson, W. S. B.: The Physics of Glaciers, 4th Edn., Elsevier, Oxford, UK, 2010. 
Enderlin, E., Howat, I. M., and Jeong, S.: An improved mass budget for the Greenland ice sheet, Geophys. Res. Lett., 41, 866-872, doi:10.1002/2013GL059010, 2014.

Gladish, C., Holland, D. M., Rosing-Asvid, A., Behrens, J. W., and Boje, J.: Oceanic Boundary Conditions for Jakobshavn Glacier. Part I: Variability and Renewal of Ilulissat Icefjord Waters, 200114, J. Phys. Oceanogr., 45, 3-31, doi:10.1175/JPO-D-14-0044.1, 2015a.

Gladish, C. V., Holland, D. M., and Lee, C. M.: Oceanic Boundary Conditions for Jakobshavn Glacier. Part II: Provenance and Sources of Variability of Disko Bay and Ilulissat Icefjord Waters, 1990-2011, J. Phys. Oceanogr., 45, 33-63, doi:10.1175/JPO-D14-0045.1, 2015b.

Hellmer, H. H. and Olbers, D. J.: A two-dimensional model for the thermohaline circulation under an ice shelf, Antarct. Sci., 1, 325336, doi:10.1017/S0954102089000490, 1989.

Hewitt, I. J., Schoof, C. and Werder, M. A.: Flotation and free surface flow in a model for subglacial drainage. Part 2. Channel flow, J. Fluid Mech., 702, 157-187, 2012.

Holland, D. M., Thomas, R. H., de Young, B., Ribergaard, M. H., and Lyberth, B.: Acceleration of Jakobshavn Isbræ triggered by warm subsurface ocean waters, Nat. Geosci., 1, 659-664, doi:10.1038/ngeo316, 2008.

Howat, I. M., Negrete, A., and Smith, B. E.: The Greenland Ice Mapping Project (GIMP) land classification and surface elevation data sets, The Cryosphere, 8, 1509-1518, doi:10.5194/tc-81509-2014, 2014.

Inall, M. E., Murray, T., Cottier, F. R., Scharrer, K., and Boyd, T. J.: Oceanic heat delivery via Kangerdlugssuaq Fjord to the southeast Greenland ice sheet, J. Geophys. Res.-Oceans, 119, 631645, doi:10.1002/2013JC009295, 2014.

Jackson, R. H., Straneo, F., and Sutherland, D. A.: Externally forced fluctuations in ocean temperature at Greenland glaciers in non-summer months, Nat. Geosci., 7, 503-508, doi:10.1038/ngeo2186, 2014

Jenkins, A.: A one-dimensional model of ice shelf-ocean interaction, J. Geophys. Res., 96, 671-677, 1991.

Jenkins, A.: The Impact of Melting Ice on Ocean Waters, J. Phys. Oceanogr., 29, 2370-2381, 1999.

Jenkins, A.: Convection-Driven Melting near the Grounding Lines of Ice Shelves and Tidewater Glaciers, J. Phys. Oceanogr., 41, 2279-2294, doi:10.1175/JPO-D-11-03.1, 2011.

Jenkins, A., Dutrieux, P., Jacobs, S. S., McPhail, S. D., Perrett, J. R., Webb, A. T., and White, D.: Observations beneath Pine Island Glacier in West Antarctica and implications for its retreat, Nat. Geosci., 3, 468-472, doi:10.1038/ngeo890, 2010.

Johnson, H. L., Münchow, A., Falkner, K. K., and Melling, $\mathrm{H}$ : Ocean circulation and properties in Petermann Fjord, Greenland, J. Geophys. Res.-Oceans, 116, 1-18, doi:10.1029/2010JC006519, 2011

Joughin, I., Alley, R. B., and Holland, D. M.: Ice-Sheet Response to Oceanic Forcing, Science, 338, 1172-1176, 2012.

Joughin, I., Das, S. B., Flowers, G. E., Behn, M. D., Alley, R. B., King, M. A., Smith, B. E., Bamber, J. L., van den Broeke, M. R., and van Angelen, J. H.: Influence of ice-sheet geometry and supraglacial lakes on seasonal ice-flow variability, The Cryosphere, 7, 1185-1192, doi:10.5194/tc-7-1185-2013, 2013.

Kimura, S., Holland, P. R., Jenkins, A., and Piggott, M.: The Effect of Meltwater Plumes on the Melting of a Vertical Glacier Face, J.
Phys. Oceanogr., 44, 3099-3117, doi:10.1175/JPO-D-13-0219.1, 2014.

Lüthi, M., Funk, M., Gogineni, S., and Truffer, M.: Mechanisms of fast flow in Jakobshavns Isbræ, Greenland, Part III. Measurements of ice deformation, temperature and cross-borehole conductivity in boreholes to the bedrock, J. Glaciol., 48, 369-385, 2002.

Mankoff, K. D., Straneo, F., Cenedese, C., Das, S. B., Richards, C. G., and Singh, H.: Structure and dynamics of a subglacial plume in a Greenland fjord, J. Geophys. Res., submitted, 2016.

Mernild, S. H., Holland, D. M., Holland, D., Rosing-Asvid, A., Yde, J. C., Liston, G. E., and Steffen, K.: Freshwater Flux and Spatiotemporal Simulated Runoff Variability into Ilulissat Icefjord, West Greenland, Linked to Salinity and Temperature Observations near Tidewater Glacier Margins Obtained Using Instrumented Ringed Seals, J. Phys. Oceanogr., 45, 1426-1445, doi:10.1175/JPO-D-14-0217.1, 2015.

Moon, T. and Joughin, I.: Changes in ice front position on Greenland's outlet glaciers from 1992 to 2007, J. Geophys. Res., 113, F02022, doi:10.1029/2007JF000927, 2008.

Morlighem, M., Rignot, E., Mouginot, J., Seroussi, H., and Larour, E.: Deeply incised submarine glacial valleys beneath the Greenland ice sheet, Nat. Geosci., 7, 18-22, doi:10.1038/ngeo2167, 2014.

Mortensen, J., Lennert, K., Bendtsen, J., and Rysgaard, S.: Heat sources for glacial melt in a sub-Arctic fjord (Godthåbsfjord) in contact with the Greenland Ice Sheet, J. Geophys. Res., 116, C01013, doi:10.1029/2010JC006528, 2011.

Morton, B. R., Taylor, G., and Turner, J. S.: Turbulent Gravitational Convection from Maintained and Instantaneous Sources, P. Roy. Soc. A, 234, 1-23, doi:10.1098/rspa.1956.0011, 1956.

Motyka, R. J., Dryer, W. P., Amundson, J., Truffer, M., and Fahnestock, M.: Rapid submarine melting driven by subglacial discharge, LeConte Glacier, Alaska, Geophys. Res. Lett., 40, 5153 5158, doi:10.1002/grl.51011, 2013.

Palmer, S., Shepherd, A., Nienow, P., and Joughin, I.: Seasonal speedup of the Greenland Ice Sheet linked to routing of surface water, Earth Planet. Sc. Lett., 302, 423-428, doi:10.1016/j.eps1.2010.12.037, 2011.

Plueddemann, A. J., Kukulya, A. L., Stokey, R., and Freitag, L.: Autonomous Underwater Vehicle Operations Beneath Coastal Sea Ice, IEEE/ASME T. Mechatron., 17, 54-64, 2012.

Post, A., O’Neel, S., Motyka, R., and Streveler, G.: A Complex Relationship Between Calving Glaciers and Climate, EOS Trans. 92, 305-312, 2011.

Rignot, E. and Kanagaratnam, P.: Changes in the velocity structure of the Greenland Ice Sheet, Science, 311, 986-990, doi:10.1126/science.1121381, 2006.

Schoof, C.: Ice-sheet acceleration driven by melt supply variability, Nature, 468, 803-806, 2010.

Schumann, K., Völker, D., and Weinrebe, W. R.: Acoustic mapping of the Ilulissat Ice Fjord mouth, West Greenland, Quaternary Sci. Rev., 40, 78-88, doi:10.1016/j.quascirev.2012.02.016, 2012.

Sciascia, R., Straneo, F., Cenedese, C., and Heimbach, P.: Seasonal variability of submarine melt rate and circulation in an East Greenland fjord, J. Geophys. Res.-Oceans, 118, 2492-2506, doi:10.1002/jgrc.20142, 2013.

Shepherd, A., Irvins, E. R., Geruo, A., Barletta, V. R., Bentley, M. J., Bettadpur, S., Briggs, K. H., Bromwich, D. H., Forsberg, R., 
Galin, N., Horwath, M., Jacobs, S., Joughin, I., King, M. A., Lenaerts, J. T. M., Li, J., Ligtenberg, S. R. M., Luckman, A., Luthcke, S. B., McMillan, M., Meister, R., Milne, G., Mouginot, J., Muir, A., Nicolas, J. P., Paden, J., Payne, A. J., Pritchard, H., Rignot, E., Rott, H., Sorensen, L. S., Scambos, T. A., Scheuchl, B., Schrama, E. J. O., Smith, B., Sundal, A. V., van Angelen, J. H., van de Berg, W. J., van den Broeke, M. R., Vaughan, D. G., Velicogna, I., Wahr, J., Whitehouse, P. L., Wingham, D. J., Yi, D., Young, D., and Zwally, H. J.: A Reconciled Estimate of Ice-Sheet Mass Balance, Science, 338, 1183-1189, 2012.

Shreve, R. L.: Movement of water in glaciers, J. Glaciol., 11, 205214, 1972.

Slater, D. A., Nienow, P. W., Cowton, T. R., Goldberg, D. N., and Sole, A. J.: Effect of near-terminus subglacial hydrology on tidewater, Geophys. Res. Lett., 42, 2861-2868, doi:10.1002/2014GL062494, 2015.

Straneo, F. and Cenedese, C.: The Dynamics of Greenland's Glacial Fjords and Their Role in Climate, Ann. Rev. Mar. Sci., 7, 89-112, doi:10.1146/annurev-marine-010213-135133, 2015.

Straneo, F. and Heimbach, P.: North Atlantic warming and the retreat of Greenland's outlet glaciers, Nature, 504, 36-43, doi:10.1038/nature12854, 2013.

Straneo, F., Hamilton, G. S., Sutherland, D. A., Stearns, L. A., Davidson, F., Hammill, M. O., Stenson, G. B., and RosingAsvid, A.: Rapid circulation of warm subtropical waters in a major glacial fjord in East Greenland, Nat. Geosci., 3, 182-186, doi:10.1038/ngeo764, 2010.

Straneo, F., Curry, R. G., Sutherland, D. A., Hamilton, G. S., Cenedese, C., Våge, K., and Stearns, L. A.: Impact of fjord dynamics and glacial runoff on the circulation near Helheim Glacier, Nat. Geosci., 4, 322-327, doi:10.1038/ngeo1109, 2011.
Straneo, F., Heimbach, P., Sergienko, O., Hamilton, G., Catania, G., Griffies, S., Hallberg, R., Jenkins, A., Joughin, I., Motyka, R., Pfeffer, W. T., Price, S. F., Rignot, E., Scambos, T., Truffer, M., and Vieli, A.: Challenges to Understanding the Dynamic Response of Greenland's Marine Terminating Glaciers to Oceanic and Atmospheric Forcing, B. Am. Meteorol. Soc., 94, 11311144, doi:10.1175/BAMS-D-12-00100.1, 2013.

Sutherland, D. A., Straneo, F., and Pickart, R. S.: Characteristics and dynamics of two major Greenland glacial fjords, J. Geophys. Res.-Oceans, 119, 3767-3791, doi:10.1002/jgrc.20224, 2014.

Tedstone, A. J. and Arnold, N. S.: Automated remote sensing of sediment plumes for identification of runoff from the Greenland ice sheet, J. Glaciol., 58, 699-712, doi:10.3189/2012JoG11J204, 2012.

Thomas, R., Frederick, E., Krabill, W., Manizade, S., and Martin, C.: Recent changes on greenland outlet glaciers, J. Glaciol., 55, 147-162, doi:10.3189/002214309788608958, 2009.

Turner, J. S.: Buoyancy effects in fluids, Cambridge University Press, 1979.

Van den Broeke, M., Bamber, J., Ettema, J., Rignot, E., Schrama, E., van de Berg, W. J., van Meijgaard, E., Velicogna, I., and Wouters, B.: Partitioning recent Greenland mass loss, Science, 326, 984 986, doi:10.1126/science.1178176, 2009.

$\mathrm{Xu}$, Y., Rignot, E., Menemenlis, D., and Koppes, M.: Numerical experiments on subaqueous melting of Greenland tidewater glaciers in response to ocean warming and enhanced subglacial discharge, Ann. Glaciol., 53, 229-234, doi:10.3189/2012/AoG60A139, 2012.

Xu, Y., Rignot, E., Fenty, I., Menemenlis, D., and Flexas, M. M.: Subaqueous melting of Store Glacier, west Greenland from three-dimensional, high-resolution numerical modeling and ocean observations, Geophys. Res. Lett., 40, 4648-4653, doi:10.1002/grl.50825, 2013. 